\title{
Iron homeostasis in the lung
}

\author{
ANDREW J GHIO ${ }^{1}$, JENNIFER L TURI ${ }^{2}$, FUNMEI YANG $^{3}$, LAURA M GARRICK $^{4}$ \\ and MICHAEL D GARRICK ${ }^{4}$
}

\author{
${ }^{1}$ National Health and Environmental Effects Research Laboratory, Office of Research and Development, \\ United States Environmental Protection Agency, Research Triangle Park, North Carolina 27711, USA \\ ${ }^{2}$ Duke University Medical Center, Durham, North Carolina 27710, USA \\ ${ }^{3}$ Department of Cellular and Structural Biology, University of Texas Health Science Center, San Antonio, \\ Texas, 78284. USA \\ ${ }^{4}$ Department of Biochemistry, SUNY, Buffalo, New York 14214, USA
}

\begin{abstract}
Iron is essential for many aspects of cellular function. However, it also can generate oxygen-based free radicals that result in injury to biological molecules. For this reason, iron acquisition and distribution are tightly regulated. Constant exposure to the atmosphere results in significant exposure of the lungs to catalytically active iron. The lungs have a mechanism for detoxification to prevent associated generation of oxidative stress. Those same proteins that participate in iron uptake in the gut are also employed in the lung to transport iron intracellularly and sequester it in an inactive form within ferritin. The release of metal is expedited (as transferrin and ferritin) from lung tissue to the respiratory lining fluid for clearance by the mucocilliary pathway or to the reticuloendothelial system for long-term storage. This pathway is likely to be the major method for the control of oxidative stress presented to the respiratory tract.
\end{abstract}

Key terms: Lung diseases, oxidative stress, SLC11A2 protein, SLC40A1 protein

\section{INTRODUCTION}

Iron is an essential micronutrient utilized in almost every aspect of normal cell function. The chemistry of iron presents difficulties in its acquisition by the cell. In aqueous solutions, $\mathrm{Fe}^{3+}$ forms oxyhydroxides which generally are biologically inaccessible. As a result, cells have developed specific strategies to procure adequate iron for cellular function and homeostasis. In the gastrointestinal tract, ferritin, duodenal cytochrome b (Dcytb), divalent metal transporter-1 (DMT1), ferroportin (FPN1), transferrin and its receptor, lactoferrin and its receptor, xanthine oxidoreductase, and ceruloplasmin/hephaestin have been postulated to participate in the transport of iron to meet the nutritional requirements for this metal.

The atmosphere constitutes a vehicle for the movement and redistribution of metals (20). Iron is the metal in greatest abundance in almost all atmospheric environments. A human breathing at a normal rate can expose the lungs to approximately ten micrograms of iron daily. Iron can catalyze electron exchange with the subsequent generation of oxidants that can damage host tissues. Ironcatalyzed oxidative stress also can participate in lung injury after exposure to many agents that have a capacity to disrupt normal iron homeostasis in the lung (frequently by complex formation with

Correspondence to: Andrew J. Ghio, Campus Box 7315, Human Studies Division, US EPA, 104 Mason Farm Road, Chapel Hill, North Carolina 27599-7315, USA, Tel.: (1-919) 966-0670, Fax: (1-919) 966-6271, E-mail: ghio.andy@epa.gov

Received: March 3, 2005. Accepted: May 3, 2005.

Disclaimer: This report has been reviewed by the National Health and Environmental Effects Research Laboratory, United States Environmental Protection Agency and approved for publication. Approval does not signify that the contents necessarily reflect the views and policies of the Agency nor does mention of trade names or commercial products constitute endorsement or recommendation for use. 
available host metal). These exposures include inorganic particles (e.g. silica and silicates), cigarette smoke, hyperoxia, hypoxia, bleomycin, paraquat, and endotoxin (16). Pulmonary diseases, such as infectious pneumonia, chronic obstructive pulmonary disease, cystic fibrosis, sarcoidosis, interstitial lung disease, acute respiratory distress syndrome, bronchogenic carcinoma, and sepsis, involve a similar disruption of normal iron metabolism and oxidative stress in the lower respiratory tract.

These challenges make it likely that means of isolating iron in a chemically less reactive form evolved in the lungs to detoxify catalytically active iron and allow normal function. Those same proteins involved in transporting iron in the gastrointestinal tract to meet the nutritional requirements for this metal apparently participate in a transport of iron in the lung to meet the needs of this tissue in sequestering metal and preventing catalyzed oxidative stress (Fig. 1).

\section{RESULTS AND DISCUSSION}

\section{Iron uptake by lung epithelial cells}

Iron can be transported to an intracellular pool by a variety of cell types from a medium that contains no transferrin. Such transport has been demonstrated for microbes, plant cells, and selected animal cells. Uptake of iron by lung epithelial cells is also both time- and concentrationdependent (Figs. 2A and 2B). Measurement of non-heme iron concentrations in the cell (Fig. 2C) and fluorescence studies confirm that the metal is transported to the cell interior (Fig. 2D).

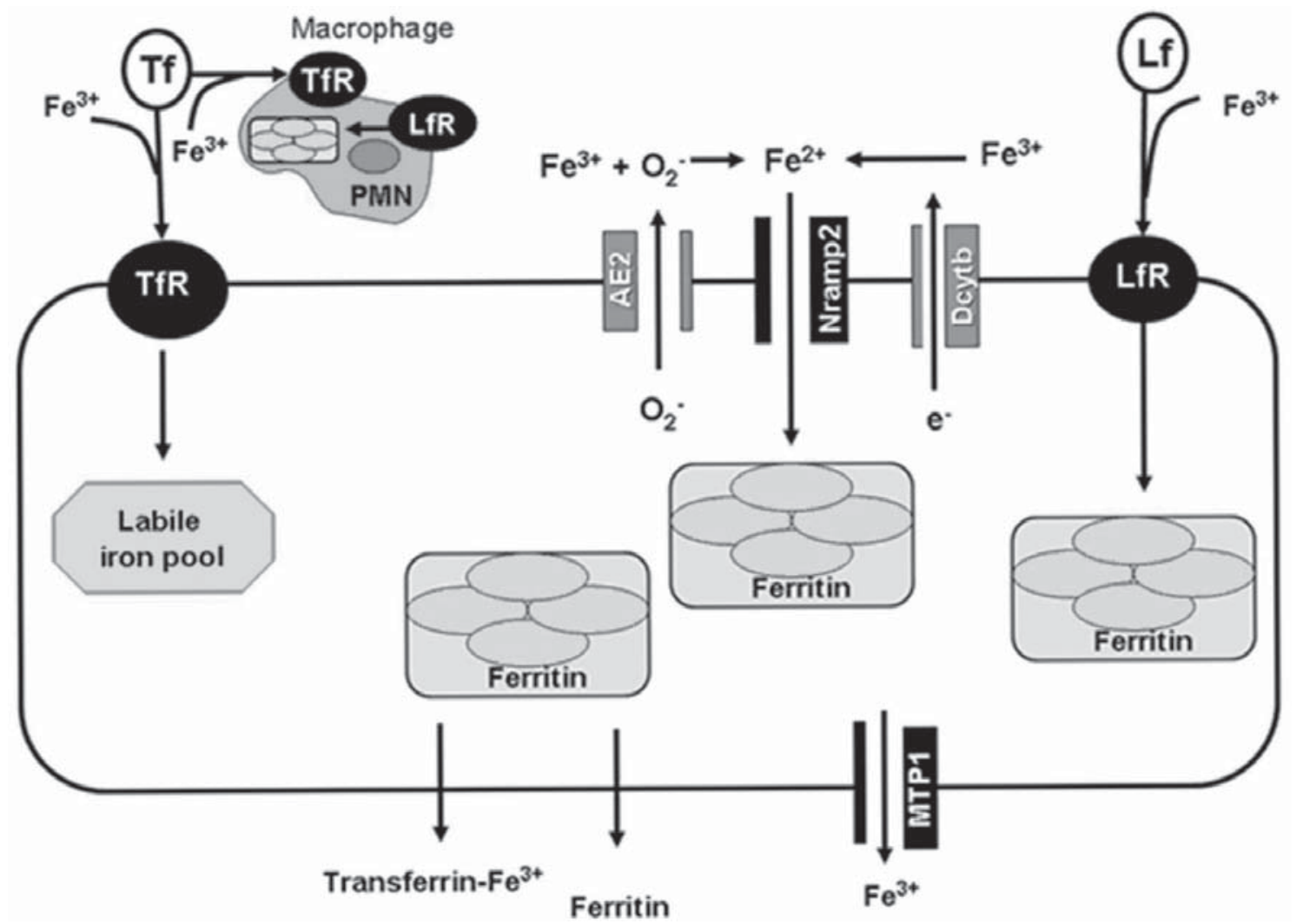

Figure 1. Proposed transport of iron by the lung to maintain homeostasis. Exposure of the lung to both iron and high levels of 02 put it at significant risk for oxidant injury. A mechanism is required for detoxification of iron in the lung. A manner of transport comparable to that in the duodenum employed to meet the nutritional requirements of the system is proposed. 

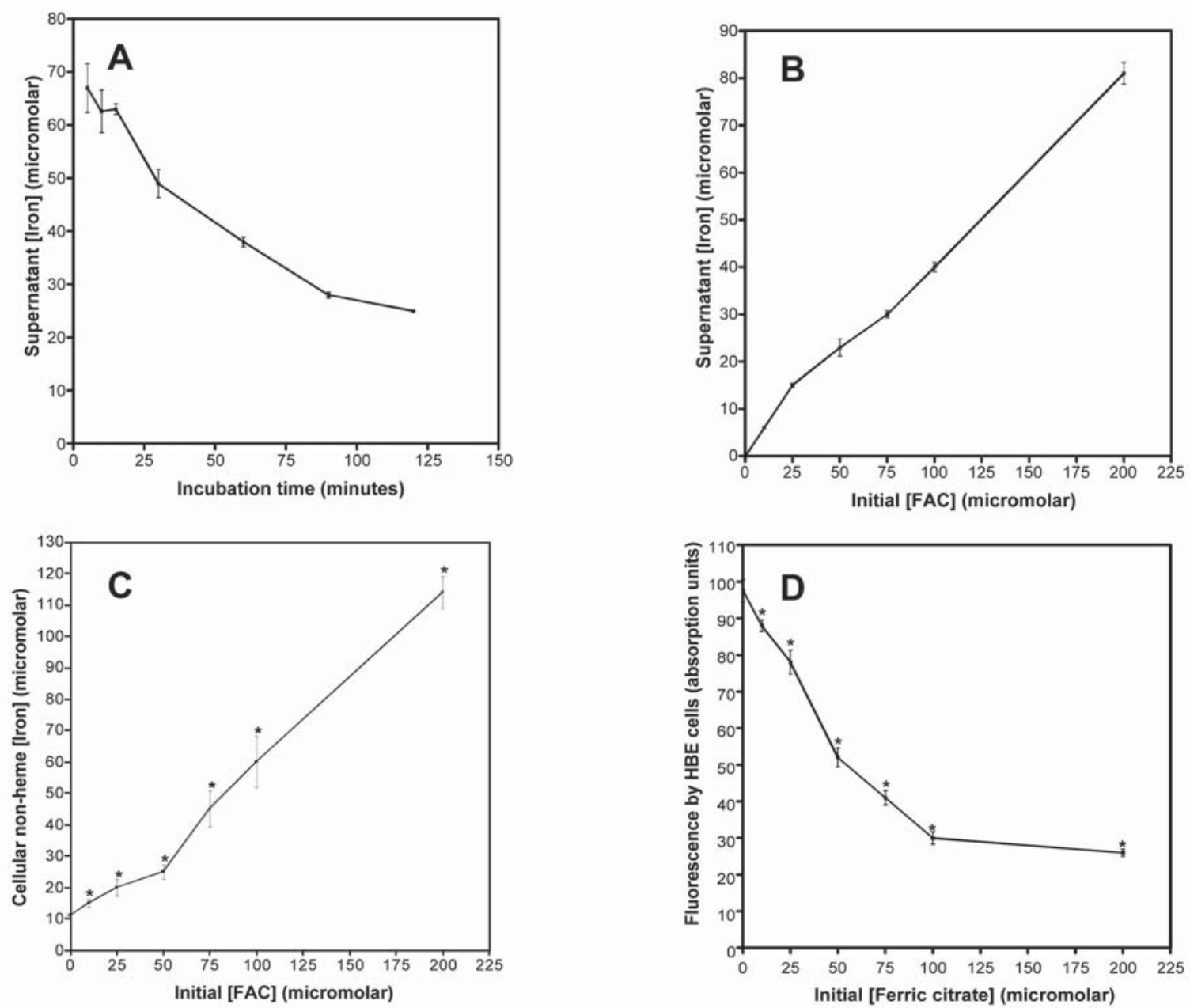

Figure 2. Panel A: Time-dependence of iron uptake by respiratory epithelial cells (BEAS-2B cells). Cells were grown in 12-well plates to $90-100 \%$ confluence in KGM. The media was then switched to HBSS and the cells exposed to $100 \mu \mathrm{M}$ FAC. Supernatant was removed, and after centrifugation at $600 \mathrm{~g} \mathrm{x} 10$ minutes, iron was measured using ICPAES $(\lambda=238.204) ; \mathrm{n}=6)$. Panel B: Concentration-dependence of metal uptake by BEAS-2B cells. Cells were grown in KGM, the media switched to HBSS, and the cells exposed to FAC for 60 minutes. Supernatant was removed, and after centrifugation at $600 \mathrm{~g} \mathrm{x} 10$ minutes, iron was measured using ICPAES $(\lambda=238.204)$; $\mathrm{n}=$ 6. Panel C: Cellular non-heme iron concentrations. Cells were grown to $90-100 \%$ confluence on plastic 12-well plates in $1.0 \mathrm{~mL} \mathrm{KGM.} \mathrm{The} \mathrm{media} \mathrm{then} \mathrm{was} \mathrm{switched} \mathrm{to} \mathrm{HBSS,} \mathrm{and} \mathrm{the} \mathrm{cells} \mathrm{were}$ exposed to FAC ( 0 to $200 \mu \mathrm{M}$ ) for 1 hour. The supernatant was removed and $1.0 \mathrm{~mL} 3 \mathrm{~N} \mathrm{HCl}$ with $10 \%$ trichloroacetic acid added. The cells were scraped into the acid and hydrolyzed at $70^{\circ} \mathrm{C}$ for 18 hours. After centrifugation at $600 \mathrm{~g}$ x 10 minutes, the concentration of iron in the supernatant was determined using ICPAES $(\lambda=238.204) . * p<0.05$ relative to non-heme [iron] of cells exposed to media alone; $n=6$. Panel D: Fluorescence for intracellular iron. BEAS-2B cells were grown to 90$100 \%$ confluence on plastic 12 -well plates in KGM. This was exchanged for media with $0.5 \mu \mathrm{M}$ calcein-AM. After incubation for 1 hour at $37^{\circ} \mathrm{C}$, excess calcein-AM was removed and the cells washed twice with HBSS. Buffer alone or FAC ( 0 to $200 \mu \mathrm{M})$ in HBSS was added to the BEAS-2B cells for 1 hour. The supernatant was then removed, the cells washed twice with HBSS, and the intensity of the fluorescence signal was measured with excitation at $486 \mathrm{~nm}$ and emission at 517 $\mathrm{nm}$. Prior to exposure to calcein-AM, BEAS-2B fluorescence was $4.8 \pm 0.3$ absorption units. * $\mathrm{P}<$ 0.05 relative to fluorescence of cells exposed to calcein-AM followed by HBSS; $n=6$. 


\section{Ferritin in lung epithelial cells}

The mechanism of sequestration of iron employed by all living systems requires its ultimate storage within ferritin (6). Storage within ferritin limits the capacity of iron to generate free radicals and confers an antioxidant function (2). The synthesis of this protein is regulated by a posttranscriptional mechanism (14). A hairpin sequence at the 5'-untranslated end of ferritin mRNA, called the iron responsive element (IRE), binds a cubane iron-sulfur cluster, the iron regulatory proteins (IRPs). Available iron reacts with IRPs to decrease their binding to the mRNA. Translation of ferritin proceeds. The concentration of ferritin in the lung lining fluid is extremely high, reflecting the direct interaction of this tissue with iron in the external environment (10). Lung epithelial cells exposed to iron demonstrate a significant elevation in cell ferritin (Fig. 3).

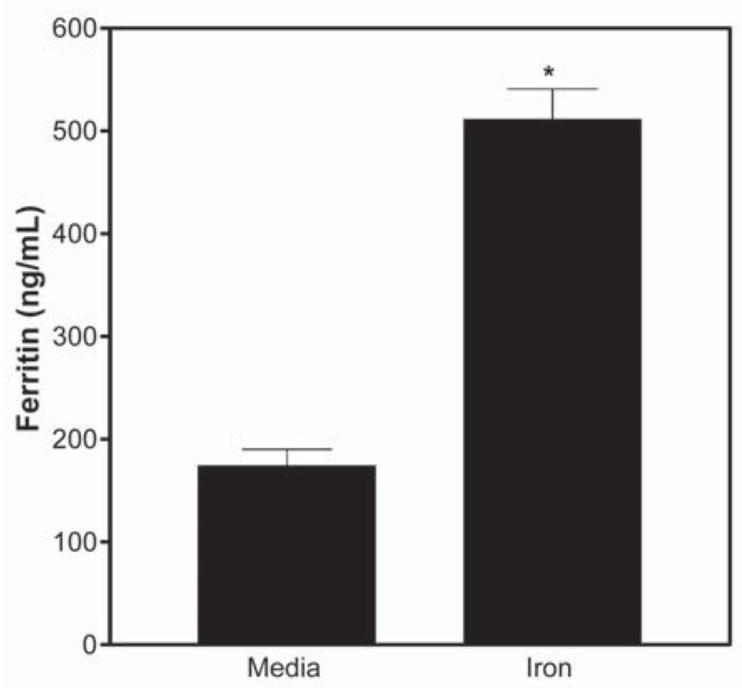

Figure 3. Ferritin concentrations in lung epithelial cells with and without exposure to iron. BEAS-2B cells were exposed to media or FAC $100 \mu \mathrm{M}$, for 24 hours. Supernatant was removed, the cells were washed with HBSS, and lysed in $1.0 \mathrm{~mL}$ HBSS, and concentrations of ferritin protein were determined using a commercially available enzyme immunoassay. * $\mathrm{P}<0.05$ relative to exposure to media alone
Ferrireductase activity in lung epithelial cells

While ferritin is produced intracellularly, iron and many of the chelates that present an oxidative stress to the cell are extracellular. Therefore, the sequestration and detoxification of this metal by ferritin requires that the metal be transported across the cell membrane. Iron frequently is transferred across membranes via transferrin or lactoferrin and their respective receptors. While transferrin plays a significant role in nutritional uptake of iron, the metal is not sequestered within ferritin, but rather, released into a catalytically active low molecular weight pool (3). This release results in iron readily available to support numerous cellular functions but also allows the metal to remain available to catalyze reactions with molecular oxygen. Such transport cannot be viewed as limiting oxidative stress. Conversely, lactoferrin rarely provides metal for nutritional requirements. Rather, its location at sites of interaction between a host and its external environment, i.e. in secretory epithelium, suggests a potential role in a detoxification of metal. However, the small concentrations of this glycoprotein in the lung restrict its role in metal transport there.

Non-transferrin (or non-lactoferrin) bound iron (NTBI) uptake provides an alternative means of transporting metal by complexing low molecular weight forms of iron to endogenous ligands. Ferrireductase activity appears to be required prior to uptake of $\mathrm{Fe}^{2+}$ by means of a metal carrier protein. In plant cells, chemical reduction of $\mathrm{Fe}^{3+}$ to $\mathrm{Fe}^{2+}$ is mediated by superoxide $\left(\cdot \mathrm{O}_{2}^{-)}\right.$anion (5) produced by enzymes such as $\mathrm{NAD}(\mathrm{P}) \mathrm{H}$ : flavin oxidoreductases at the cell surface where metal reduction occurs (4). The final electron acceptor, molecular $\mathrm{O}_{2}$, generates $\mathrm{O}_{2}^{-}$, which reduces $\mathrm{Fe}^{3+}$ and splits the metal chelate apart. Uptake of $\mathrm{Fe}^{2+}$ by metal carrier proteins then occurs on the apoplastic surface of the cell. Investigation demonstrates that superoxide can participate in ferrireduction in lung epithelial cells. MnSOD significantly decreased the formation of ferrous chelate 
in respiratory epithelial cells exposed to ferric ammonium citrate (Fig. 4). Numerous potential sources of superoxide exist in mammalian cells (7). In the proximal duodenum, iron acquisition may depend on the reducing ability of duodenum cytochrome $b$ (Dcytb) (17). Our preliminary evidence identifies Dcytb expression in airway epithelial cells and raises the possibility that it may be a potential source of $\mathrm{O}_{2}^{-}$for the reduction of ferric iron in the lung.

\section{Anion exchange $(A E)$ proteins}

AE proteins are membrane-bound proteins that mediate electroneutral exchange of chloride $\left(\mathrm{Cl}^{-}\right)$and bicarbonate $\left(\mathrm{HCO}^{-}\right)$ions across the cell membrane to regulate intracellular $\mathrm{pH}$ and cell volume. AE proteins also have the capacity to transport $\mathrm{O}_{2}^{-}$across the cell membrane in exchange for extracellular $\mathrm{HCO}_{3}^{-}$(15). In $\mathrm{HBE}$ cells, the reduction of ferric iron and transmembrane iron transport can be inhibited by the presence of stilbene compounds (relatively specific inhibitors of AE proteins) (Fig. 5) and by treatment with antisense oligonucleotides to AE2 (Fig. 6). These findings support the existence of a transport system in the lung for transferrinindependent iron that employs superoxide transport by anion exchange protein 2 .

\section{DMT1 in lung epithelial cells}

DMT1 is a member of the natural resistance-associated macrophage proteins (Nramp), a small family of structurally and functionally related polypeptides which represent a group of transporters in vertebrates. They have been conserved across numerous species with homologues identified in yeasts, bacteria, worms, flies,
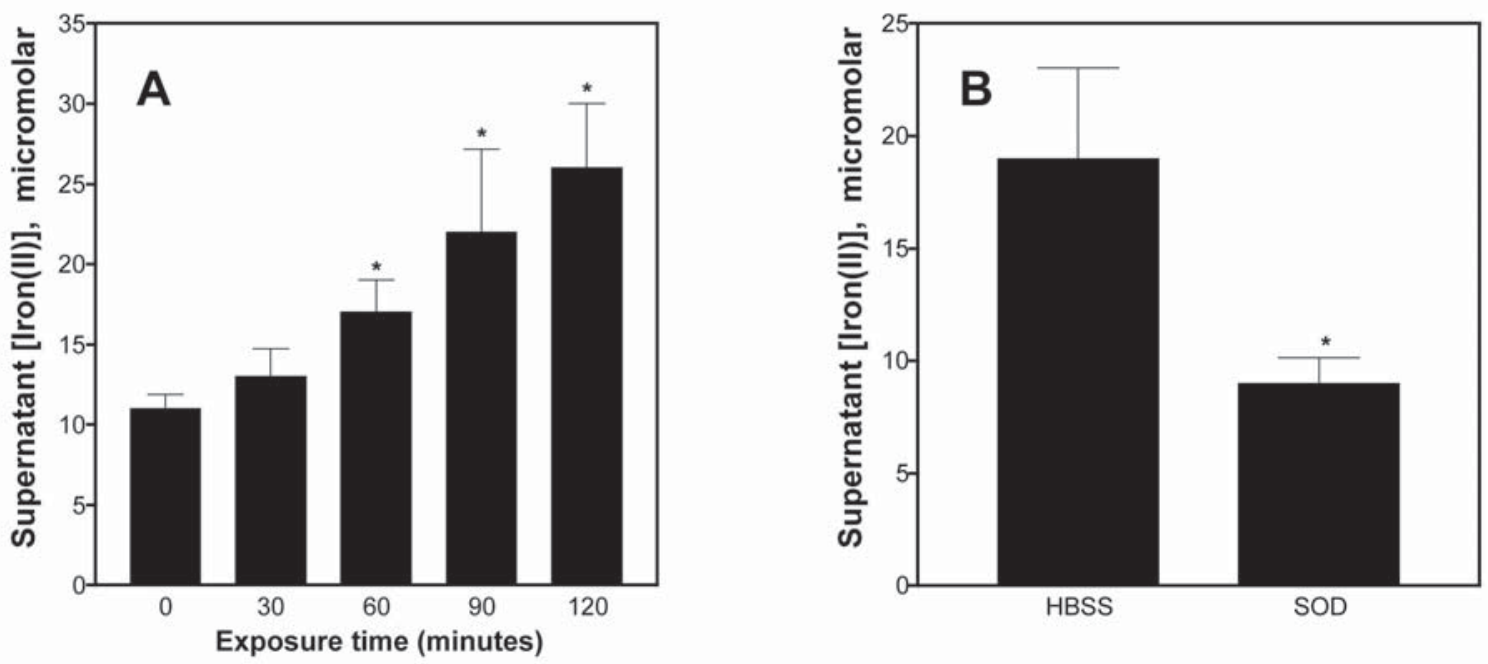

Figures 4A and 4B. Participation of superoxide in ferrireduction by lung epithelial cells. Epithelial cells were grown in $75 \mathrm{~cm} 2$ tissue culture flasks to $90-100 \%$ confluence submerged. The media was switched to HBSS and $50 \mu \mathrm{M}$ FAC and $100 \mu \mathrm{M}$ BPS was added. After incubation at $37^{\circ} \mathrm{C}$ (at $5 \%$ $\mathrm{CO}_{2}$ ), supernatant was removed and the concentration of the ferrous chelate of BPS was measured by absorbance at $520 \mathrm{~nm}$. Relative to $\left[\mathrm{Fe}^{2+}-\mathrm{BPS}\right]$ at 0 minute, the concentration of ferrous chelate significantly increased at all other time points (A). The experiment was repeated. After the media was removed, $10 \mathrm{~mL}$ of either HBSS or HBSS containing 100 units $\mathrm{MnSOD} / \mathrm{mL}$ was added. Ten minutes later, $50 \mu \mathrm{M}$ FAC and $100 \mu \mathrm{M}$ BPS were added to the flasks. After 1 hour at $37^{\circ} \mathrm{C}(5 \%$ $\mathrm{CO}_{2}$ ), supernatant was removed and the ferrous chelate of BPS was measured. MnSOD significantly decreased ferrous chelate formation after exposure of respiratory epithelial cell to FAC $(\mathbf{B}) .{ }^{*} \mathrm{P}<0.05$ relative to iron concentrations at time of exposure $=0$ and with HBSS respectively 
and plants. Evolutionary conservation suggests that a fundamental function may be common to all these proteins. DMT1, expressed in most tissues and cell types as an integral membrane protein (molecular weight of 90 to $100 \mathrm{kD}$ ) modified by glycosylation (23) functions to transport divalent metal cations including $\mathrm{Fe}^{2+}$ (12).

In the proximal duodenum, after $\mathrm{Fe}^{3+}$ is reduced to $\mathrm{Fe}^{2+}$, it then is transported into the epithelial cell by DMT1 (27). The same missense mutation in DMT1 is carried by both microcytic anemia $(m k)$ mice and Belgrade rats (9) (21). Consequently, both the $m k$ mouse and the Belgrade rat demonstrate diminished intestinal iron absorption. The inherited defect of iron uptake in these naturally occurring animal mutants corroborated that DMT1 is the transferrin-independent system responsible for dietary iron absorption in the intestine. The ubiquitous expression of DMT1 suggests that it might be involved in transferrin-independent iron uptake.

DMT1 generates two alternatively spliced mRNAs that differ at their $3^{\prime}$ untranslated region by either the presence or absence of an iron-response element (IRE). IREs are found in noncoding portions of mRNA for specific proteins that can be regulated post-transcriptionally in response to cellular iron levels. mRNA for DMT1 increases after lung epithelial cell exposures to iron, but this increment was specific for the -IRE isoform (Fig. 7). Similarly, Western blot analysis demonstrates elevations in expression of IRE DMT1 but not the +IRE isoform (Fig. 8). Immunohistochemistry of the rat lung also supports an upregulation of -IRE DMT1 following exposure of the lung to iron (26). This result contrasts with the response of intestinal cells in which iron depletion increases the mRNA level of

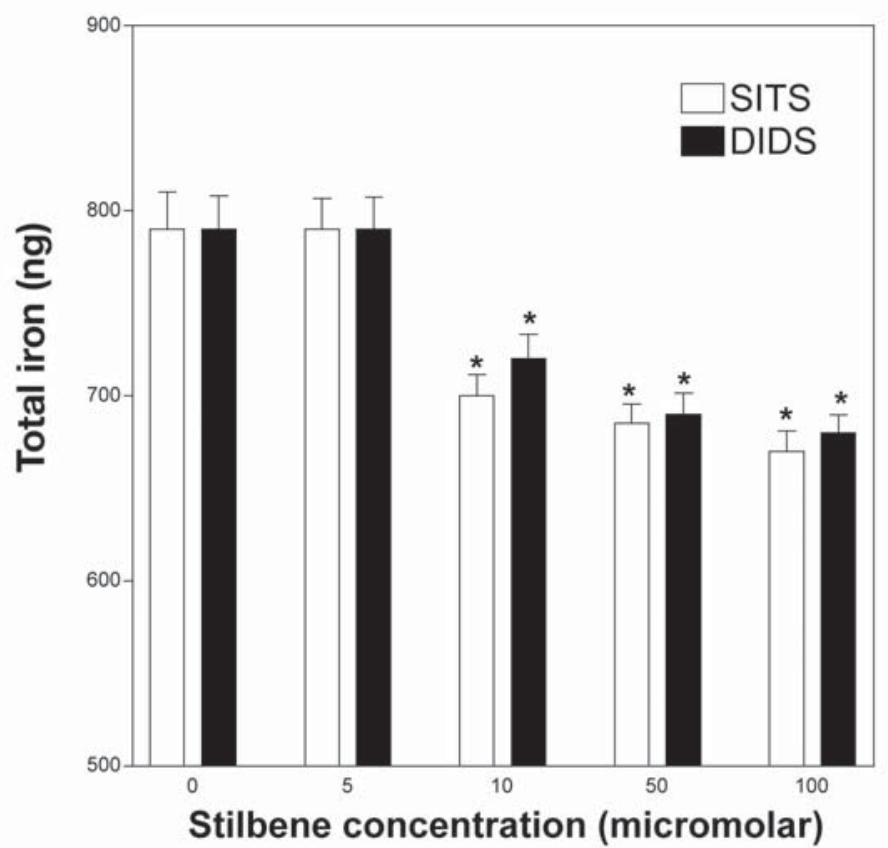

Figure 5. Inhibition of iron uptake in HBE by stilbene compounds. Cells were grown at an airliquid interface, the media switched to HBSS before adding 0 to $100 \mu \mathrm{M} 4,4^{\prime}$ diisothiocyanatostilbene-2,2'-disulfonic acid (DIDS) or 4-acetamido-4'-isothiocyanatostilbene2,2'disulfonic acid (SITS). Ten min later, $100 \mu \mathrm{M}$ FAC was added to the incubation. After $4 \mathrm{~h}$, the cells were washed in HBSS, scraped into $2 \mathrm{~mL} 3 \mathrm{~N} \mathrm{HCl}$ and $10 \%$ trichloroacetic acid, and hydrolyzed at $70^{\circ} \mathrm{C}$ for $18 \mathrm{~h}$. Iron was then measured using ICPAES $\lambda=238.204$ ). Both DIDS and SITS significantly decreased cellular uptake of iron by the cells. $* \mathrm{P}<0.05$ relative to HBE cells exposed to neither DIDS nor SITS. 


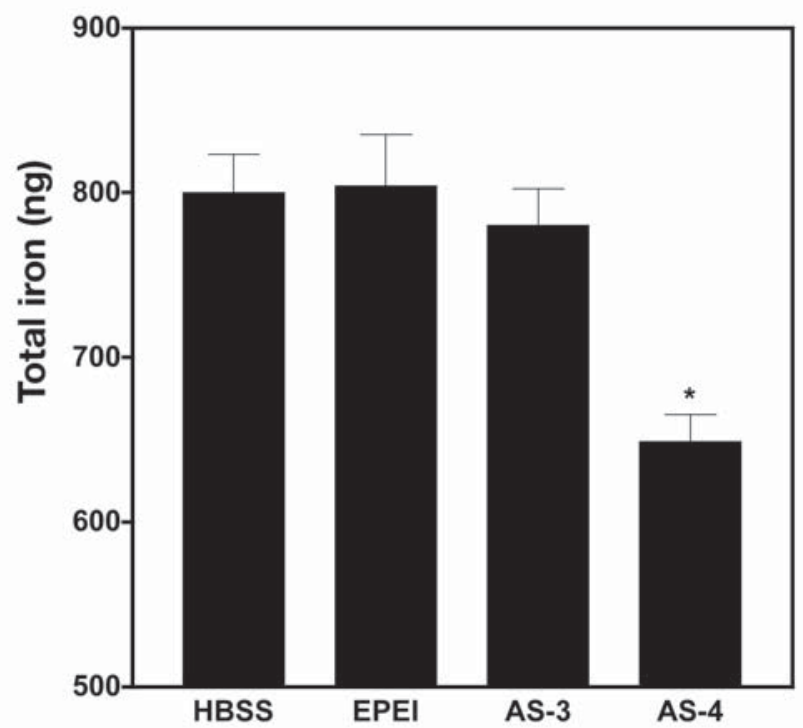

Figure 6. Decreased iron transport after AE2 antisense treatment. Respiratory epithelial cells were treated with the delivery agent (EPEI) for $20 \mathrm{~min}$, and the complexes were diluted with Opti-Mem in the Transwell plates. The complexes were removed from the cells after a 3 -h incubation at $37^{\circ} \mathrm{C}$. Eighteen hours later, media was switched to HBSS and the cells exposed to $50 \mu \mathrm{L}$ of $100 \mu \mathrm{M}$ FAC. After $4 \mathrm{~h}$, the cells were washed, scraped into $2 \mathrm{~mL} 3 \mathrm{~N} \mathrm{HCl}$ in $10 \%$ trichloroacetic acid, and hydrolyzed at $70^{\circ} \mathrm{C}$ for $18 \mathrm{~h}$. Iron was measured using ICPAES (_ 238.204). Cells treated with AS4 showed significant decreases in iron uptake. $* \mathrm{P}<0.05$ relative to HBSS.

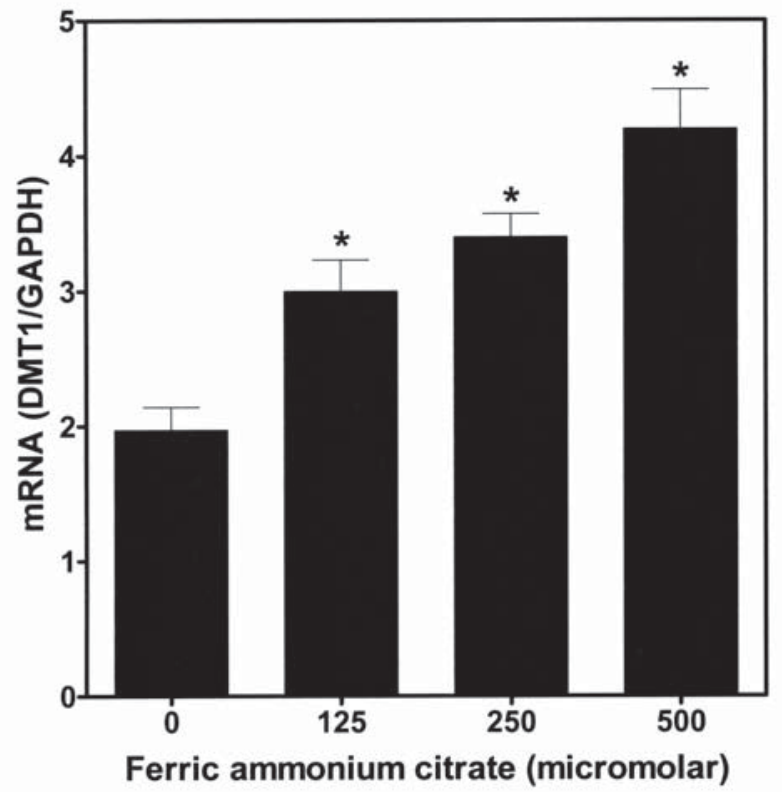

Figure 7. DMT1 mRNA by RT-PCR in lung epithelial cells with and without exposure to iron. Cells were grown in KGM and exposed to $0,125,250$, and $500 \mu \mathrm{M}$ FAC for 24 hours. Total RNA was extracted and reverse-transcribed. Quantitative PCR was performed using Taqman polymerase with detection of Syber Green fluorescence on an ABI Prism 7700 Sequence detector (PE Biosystems). Shown is the relative fluorescence for each band of mRNA for DMT1 without an IRE normalized to the corresponding GAPDH mRNA. * Significant increase relative to incubation with media; $\mathrm{n}=6$. 


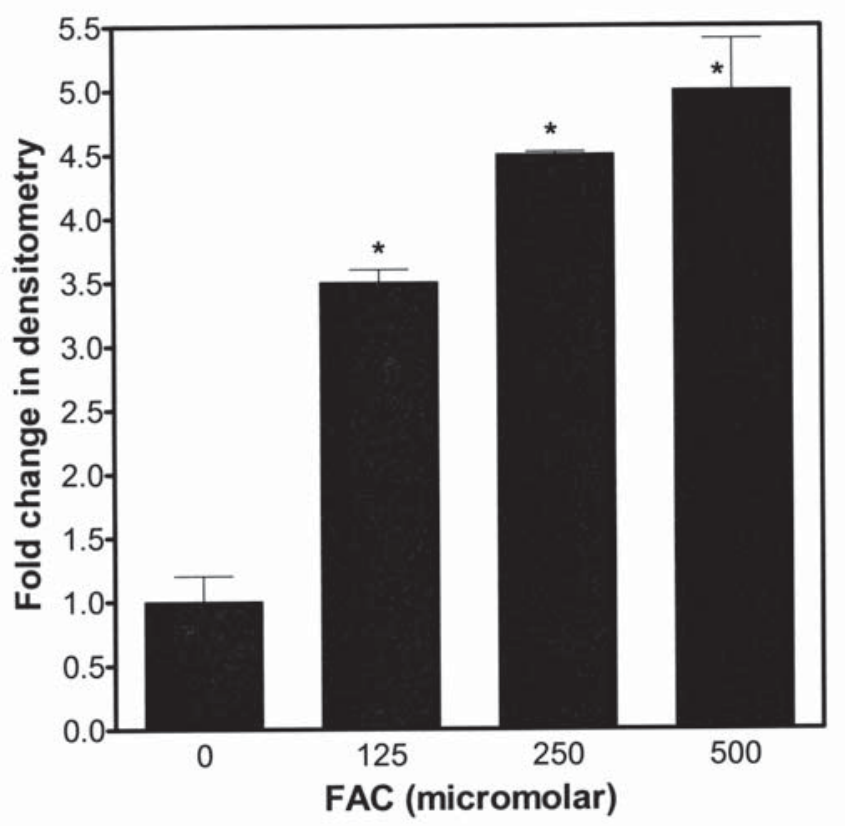

Figure 8. Analysis for DMT1 expression in lung epithelial cells with and without exposure to iron. Cells were grown in KGM and exposed to 0, 125, 250, and $500 \mu \mathrm{M}$ FAC for 24 hours. Western blot analysis was done. The intensity of the band at $90 \mathrm{kD}$ was increased with exposure to FAC. The negative (Type 55 film, Polaroid Corp., Cambridge, MA) was quantitated using a BioImage Densitometer (BioImage, Ann Arbor, MI). Densitometry measurements are graphed relative to bands exposed to media only. * Significant increase relative to incubation with media; $n=6$.

+IRE DMT1 (13). However, the mRNA level for -IRE DMT1 in hepatocytes increased after iron exposure (22). In cells and tissues that do not function to meet the nutritional requirements of the living system, a transcriptional control of DMT1 expression by iron may serve to diminish the oxidative stress and injury that this metal presents.

\section{Ferroportin 1 and lung epithelial cells}

While cellular uptake of excess iron limits the degree of toxicity in the lung, storage indefinitely in this intracellular site is vulnerable to mobilization. Therefore, a mechanism of metal transport out of the cell for storage in the reticuloendothelial system or clearance by the mucocilliary pathway is necessary to prevent excessive intracellular accumulation. There have been several major findings in the export of iron at the cellular level including the discovery of the transmembrane iron transporter ferroportin (FPN1, MTP1, Ireg 1, or SLC40A1). This protein occurs most abundantly in enterocytes but also is synthesized in other cells, including macrophages in the liver (Kupffer cells) and spleen. In the duodenal epithelium, FPN1 is localized to the basolateral membrane, while DMT1 is present mainly in the apical membrane (18). Several lines of evidence indicate that FPN1 is required for iron export to the circulation: 1) a mutation in the FPN1 gene leads to hemochromatosis and iron toxicity in affected humans (19); 2) the sex-linked anemia mouse is defective in hephaestin, a copper-based enzyme that appears important as a ferroxidase and is unable to export iron out of the intestinal epithelial cell despite total body iron depletion (25). This conversion of ferrous to ferric ion is apparently required for the function of FPN1 in the intestine. In addition, zebrafish carrying FPN1 mutations were impaired in 
the transport of iron from maternally derived yolk stores to the circulation (8). Conversely, over-expression of FPN1 in tissue culture cells resulted in intracellular iron depletion (1).

Iron augments the expression of FPN1 gene in airway epithelial cells both in vivo and in cultured cells (Table 1). The molecular mechanism for the differential regulation of both DMT1 and FPN1 by iron in different tissues is not known but may be related to tissue-specific roles of these two proteins in iron homeostasis. Both proteins, which play key roles in iron absorption in the intestine, appear to participate in iron recycling and detoxification in the lung. Similarly, FPN1 expression in the liver and the spleen is related to scavenging iron from senescent erythrocytes (1).

TABLE 1

Quantitative Analysis of FPN1 Gene Expression in BEAS-2B Cells Exposed Iron

\begin{tabular}{lcccc}
\hline FAC (micromolar) & 0 & 125 & 250 & 500 \\
\hline $\begin{array}{l}\text { *Relative amount } \\
\text { of 90-110 kD FPN1 }\end{array}$ & 1.00 & 1.57 & 1.71 & 2.73 \\
$\begin{array}{l}\text { **Relative amount } \\
\text { of FPN1 mRNA }\end{array}$ & 1.00 & 1.44 & 2.08 & 3.85 \\
\hline
\end{tabular}

* Relative amounts of FPN1 protein were analyzed by measuring the intensities of the 90-110 kD FPN1reactive bands in immunoblots using a densitometer. Data represent the mean values obtained from two experiments.

** The FPN1 mRNA levels were measured by the method of real time RT-PCR. Data were calculated from the ratios of FPN1 mRNA/GAPDH mRNA and represent the mean values obtained from four experiments.

\section{Alveolar macrophages and iron homeostasis in the lung}

The alveolar macrophage is extremely adept at metal transport. Several different mechanisms can mediate the uptake of iron in the macrophage, including the lactoferrin and transferrin pathways, DMT1, and Nramp1. Nramp1 is a 90 to $100 \mathrm{kD}$, transmembrane phosphoglycoprotein with $77 \%$ homology and a very similar secondary structure to DMT1 (11). Nramp1 confers resistance to intracellular pathogens through an uptake of divalent cations including ferrous ions (24). Such transport results in a deficiency in metal requisite for replication of microbes. During an inflammatory state, metal can also be transported across cell membranes of monocytes and macrophages by lactoferrin. Transferrin, likewise, is abundant in the respiratory lining fluid. Although transferrin associated with epithelial cells is typically involved with acquisition of iron to fulfill specific functions and nutritional requirements, metal transported by transferrin into alveolar macrophages is sequestered in ferritin. Iron is released from macrophages via transferrin, ferritin, and FPN1, though despite this, alveolar macrophages accumulate iron to high levels. Continued delivery of iron to the macrophage can overwhelm the capacity of ferritin to store and sequester the metal. The resultant oxidative injury to the cell is associated with a production of hemosiderin (or a comparable product), which stains positively in the Perl's Prussian blue reaction (i.e. the siderophage).

\section{Neutrophils and iron homeostasis in the lung}

If respiratory epithelial cells and alveolar macrophages are unable to reestablish iron equilibrium during periods of elevated metal availability and oxidative stress, the metal can be taken up and metabolized by neutrophils. Neutrophils release secondary granules that contain lactoferrin; this can complex with $\mathrm{Fe}^{3+}$ and be taken up by macrophages or respiratory epithelial cells for storage within ferritin. However, neutrophils also produce reductants such as ascorbate and superoxide; these can reduce $\mathrm{Fe}^{3+}$ to $\mathrm{Fe}^{2+}$ and further exacerbate the level of oxidative stress.

\section{CONCLUSIONS}

Despite careful regulation of iron procurement and distribution in the gut, the lungs are continually exposed to excess 
iron. Increased availability of catalytically reactive iron can result in tissue injury and contribute to the pathogenesis of several diseases by generating oxidative stress. The lower respiratory tract is afforded antioxidant protection by a number of antioxidants including glutathione, ceruloplasmin, vitamin $\mathrm{E}$, and vitamin $\mathrm{C}$. In addition to these antioxidants, the lower respiratory tract can mitigate the potential oxidative stress presented by iron in the atmosphere by transporting this metal into the cell for storage in a chemically less reactive form. NTBI transport provides a means of iron detoxification in the lung by reducing $\mathrm{Fe}^{3+}$, transporting it through a metal carrier, and incorporating the metal within intracellular ferritin. The metal subsequently can be released from the cell by FPN1 and transported out of the lung via either the mucocilliary pathway for clearance or the reticuloendothelial system for long-term storage.

\section{REFERENCES}

1. ABBOUD S, HAILE DJ (2000) A novel mammalian iron-regulated protein involved in intracellular iron metabolism. J Biol Chem, 275: 19906-19912

2. BALLA G, JACOB HS, BALLA J, ROSENBERG M, NATH K, APPLE F, EATON JW, VERCELLOTTI GM (1992) Ferritin: A cytoprotective antioxidant stratagem of endothelium. J Biol Chem 267: 18148-18153

3. BREUER W, EPSZTEJN S, CABANTCHIK ZI (1995) Iron acquired from transferrin by K562 cells is delivered into a cytoplasmic pool of chelatable iron (II). J Biol Chem 270: 24209-24215

4. BUCKHOUT TJ, BELL PF, LUSTER DG, CHANEY RL (1989) Iron-stress induced redox activity in tomato (Lycopersicum esculentum Mill.) is localized on the plasma membrane. Plant Physiol 90: 151-156

5. CAKMAK I, VAN DE WETERING DAM, MARSCHNER H, BIENFAIT HF (1987) Involvement of superoxide radical in extracellular ferric reduction by iron-deficient bean roots. Plant Physiol 85: 310-314

6. COZZI A, SANTAMBROGIO P, LEVI S, AROSIO P (1990) Iron detoxifying activity of ferritin. Effects of $\mathrm{H}$ and $\mathrm{L}$ human apoferritins on lipid peroxidation in vitro. FEBS Lett 277: 119-122

7. CROSS AR, JONES OTG (1991) Enzymic mechanisms of superoxide production. Biochem Biophys Acta 1057: 281-298

8. DONOVAN A, BROWNLIET A, ZHOU Y, SHEPARD J, PRA SJ, MOYNIHAN J, PAW BH, DREJER A, BARUT B, ZAPATA A, LAW TC, BRUGNARALL C, LUX SE, PINKUSL GS, PINDUSL JL, KINGSLEY PD, PALIS J, FLEMING MD, ANDREWS NC, ZON LI (2000) Positional cloning of zebrafish ferroportin 1 identifies a conserved vertebrate iron exporter. Nature 403: $776-780$
9. FLEMING MD, ROMANO MA, SU MA, GARRICK LM, GARRICK MD, ANDREWS NC (1998) Nramp2 is mutated in the anemic Belgrade (b) rat: Evidence of a role for DMT1 in endosomal iron transport. Proc Natl Acad Sci USA 95: 1148-1153

10. GHIO AJ, CARTER JD, RICHARDS JH, BRIGHTON LE, LAY JC, DEVLIN RB (1998) Disruption of normal iron homeostasis after bronchial instillation of an iron-containing particle. Am J Physiol 274: L396403

11. GRUENHEID S, CELLIER M, VIDAL S, GROS P (1995) Identification and characterization of a second mouse Nramp gene. Genomics 25: 514-525

12. GUSHIN H, MACKENZIE B, BERGER UV, GUNSHIN Y, ROMERO MF, BORON WF, NUSSBERGER S, GOLLAN JL, HEDIGER MA (1997) Cloning and characterization of a mammalian proton-coupled metal-ion transporter. Nature 388: 482488

13. HAN O, FLEET JC, WOOD RJ (1999) Reciprocal regulation of HFE and Nramp2 gene expression by iron in human intestinal cells. J Nutr 129: 98-104

14. LEIBOLD EA, MUNRO HN (1988) Cytoplasmic protein binds in vitro to a highly conserved sequence in the 5' untranslated region of ferritin heavy- and lightsubunit mRNAs. Proc Natl Acad Sci USA 85: 21712175,1988

15. LYNCH RE, FRIDOVICH I (1978) Permeation of the erythrocyte stroma by superoxide radical. J Biol Chem 253: 4697-4699

16. MATEOS F, BROCK JH, PÉREZ-ARELLANO JL (1998) Iron metabolism in the lower respiratory tract. Thorax 53: 594-600

17. MCKIE AT, BARROW D, LATUNDE-DADA GO, ROLFS A, SAGER G, MUDALY E, MUDALY M, RICHARDSON C, BARLOW D, BOMFORD A, PETERS TJ, RAJA KB, SHIRALI S, HEDIGER MA, FARZANEH F, SIMPSON RJ (2001) An ironregulated ferric reductase associated with the absorption of dietary iron. Science 291: 1755-1759

18. MCKIE AT, MARCIANI P, ROLFS A, BRENNAN K, WEHR K, BARROW D, MIRET S, BOMFORD A, PETERS TJ, FARZANEH F, HEDIGER MA, HENTZE MW, SIMPSON FJ (2000) A novel duodenal ironregulated transporter, IREG1, implicated in the basolateral transfer of iron to the circulation. Mol Cell 5: 299-309

19. NJAJOU OT, VAESSEN N, JOOSSE M, BERGHUIS B, VAN DONGEN JWF, BREUNING MH, SNIJDERS PJLM, RUTTEN WPF, SANDKUIJL LA, OOSTRA BA, VAN DUIJN CM, HEUTINK P (2001) A mutation in SLC11A3 is associated with autosomal dominant hemochromatosis. Nat Genet 28: 213-214

20. SCHROEDER WH, DOBSON M, KANE DM, JOHNSON ND (1987) Toxic trace elements associated with airborne particulate matter: A review. J Air Pollut Control Assoc 37: 1267-1285

21. SU MA, TRENOR CC, FLEMING JC, FLEMING MD, ANDREWS NC (1998) The G185R mutation disrupts function of the iron transporter Nramp2. Blood 92: 2157-2163

22. TRINDER D, OATES PS, THOMAS C, SADLEIR J, MORGAN EH (2000) Localisation of divalent metal transporter 1 (DMT1) to the microvillus membrane of rat duodenal enterocytes in iron deficiency, but to hepatocytes in iron overload. Gut 46: 270-276

23. VIDAL S, BELOUCHI A-M, CELLIER M, BEATTY B, GROS P (1995) Cloning and characterization of a second human NRAMP gene on chromosome 12q13. Mamm Genome 6: 224-230 
24. VIDAL SM, MALO D, VOGAN K, SKAMENE E, GROS P (1993) Natural resistance to infection with intracellular parasites: isolation of a candidate for Bcg. Cell 73: 469-85

25. VULPE CD, KUO YM, MURPHY TL, COWLEY L, ASKWITH C, LIBINA N, GITSCHIER J, ANDERSON GJ (1999) Hephaestin, a ceruloplasmin homologue implicated in intestinal iron transport, is defective in the sla mouse. Nat Genet 21: 195-199
26. WANG $\mathrm{X}$, GHIO AJ, YANG F, DOLAN KG, GARRICK MD, PIANTADOSI CA (2002) Iron uptake and Nramp-2/DMT1/DCT1 in human bronchial epithelial cells. Am J Physiol 282: L987-L995

27. WOOD RJ, HAN O (1998) Recently identified molecular aspects of intestinal iron absorption. J Nutr 128: 1841-1844 